\title{
National pentigraf as citizenship education innovation for millennial generations
}

\author{
A.M.A. Shofa* \\ Universitas Negeri Malang, Malang, Indonesia
}

A.W. Saputra

Universitas Katolik Widya Mandala Surabaya Kampus Madiun, Madiun, Indonesia

\begin{abstract}
Society is in the era of disruption. All fields have been disrupted, including education. Citizenship Education is one of the areas that is susceptible to disruption if it is not packaged innovatively. Internalization of values in Citizenship Education must also be delivered creatively, especially to the younger generation. One way that can be done to innovate citizenship education is through short stories in three paragraphs (pentigraf). This study discusses the making of a national pentigraf which was initiated by the Pancasila study center State University of Malang (UM) as a pioneer as well as the innovation of citizenship education for the millennial generation. The method of this research is participatory observation research because researchers are involved in providing counseling as well as training in making national pentigraf. The results of this study are (1) the national pentigraf learning strategy that can be applied by the millennial generation (2) the national collection of pentigraf books that have been published and disseminated.
\end{abstract}

Keywords: pentigraf, learning, citizenship

\section{INTRODUCTION}

The progress of information and communication technology that is increasingly widespread makes today's learners classified as children living in generation Z. According to Tapscot (2008), children called generation $Z$ were born in the era of 1998 to 2009. These children are also referred to as technology kids. They are called generation $Z$ because when they are born, information and communication technology is developing very fast. Television, cellphones, and computers were available when the children were born. Singh (2014) states that generation Z has more enemies than the previous generation. This is because generation $\mathrm{Z}$ tends to be more individualistic. Therefore, more understanding is needed to understand this generation born in the 2000 era or generation $Z$.

The mandate of Law Number 20 of 2003 concerning National Education System Article 37 paragraph 2 states that the higher education curriculum must include citizenship education, the explanation in the article is where citizenship education is intended to form students into human beings who have a sense of nationality and love for the country. But the learning problem of citizenship education in the field as stated by (Rista et al. 2018) is that Citizenship education as a subject of science taught formally to students has increasingly lost "trust" and tends to be underestimated. Moreover, there is an assumption that what is taught in citizenship education is not relevant to everyday life, especially the world of work. Moreover, the assumption is that the material for citizenship education is too complex and philosophical, so it is difficult to understand, especially

${ }^{*}$ Corresponding Author 
supported by boring teaching methods. In addition, an understanding of Citizenship Education from an early age (before following it), both concerning the material and teaching methods, is very minimal and even seems insignificant. Students tend to take it for granted especially if students who take it are from technical or exact sciences.

Reality as above is a matter of mutual reflection which is part of a good and bad educational system of learning achievement. educators are not only able to list the demands of learning achievement in students, educators are also required to be able and willing to make corrections to the construction of learning that has been taught. Including adjusting the learning process with the development of the times, the needs and characteristics of students. In addition, learning innovations by utilizing technology are also very important, so learning Citizenship Education is not only theoretical and lectured but also can display videos that contain case studies of daily life so students can be more interested and enthusiastic in participating in learning.

Based on the data exposure, an innovative forum is needed to package citizenship education to be more creative. Besides that, it is also necessary to plant national values in the millennial generation in an interesting and no longer conventional way. One container that can be used is a pentagram or short paragraph three paragraphs. According to Indriadi (2018) pentigraf is short for three paragraphs. The conciseness and attractiveness of the stories presented make pentigraf as a literary genre that is very suitable to be studied in this era of disruption. Therefore, collaboration between the fields of literature and citizenship is the basis for making this national pentigraf.

The purpose of this study is two (1) to describe the national pentigraf learning strategy that can be applied by millennial generations and (2) to describe the innovative process of making a national collection of kebangsan pentigraf books conducted at the Pancasila Laboratory of the State University of Malang.

\subsection{Pentigraf}

According to Tjahjono (2017), pentigraf is actually one of the forms of flash fiction, namely short fiction prose, although there is no standard size related to the brevity. This pentigraf was one of the mini-fiction genres that had skyrocketed in the 1980s. One of the pioneers was Tengsoe Tjahjono, a writer who actively sent his pentigraf to Suara Indonesia Malang daily (Indriadi, 2018). Besides Tengsoe, of course there are also many national writers who are involved in this field. Unfortunately, the field of pentigraf had subsided in the 1990s until the beginning of the 21 st century. Other genres began to emerge so as to be able to sink this unique genre. The emergence of Pentigraf was only felt lately after several national writers began to descend the mountain to realize the culture of literacy, especially literacy.

In 2015, Tengsoe founded a virtual literary community titled Indonesian Pentigraf Village. The community consists of various professional backgrounds. One that unites it is the love of literature and willingness to study literature. The President of the Indonesianigraphy Village is Dr. Tengsoe Tjahjono while the pentigraf makers are called pentigrafis (Priyanti, 2017). Pentigrafis initially linked their three paragraph short stories on Facebook social networks. Each member commented on each other and gave input. The idea to make pentigraf as books began to be conceived. The first pentigraf book from this community is titled Alea Towards Perfect Robot. The book turned out to be a stimulus as well as a trigger for pentigrafis to resonate the culture of writing pentigraf in various domains. One of the resonant forms is by making pentigraf together with Pancasila Cadres in the Pancasila Laboratory, State University of Malang.

The shape of the pentigraf is indeed limited to only three paragraphs, but all the elements of the story must still be presented in a pentagram. These elements are (1) character, (2) background, (3) plot, (4) theme, and other intrinsic elements. According to Budianta (in Tjahjono, 2017), pentigraf indirectly invite the reader to explore the deepest essence while extorting one story to just the essence. Therefore, readers will be able to appreciate the essence of the story and this genre is very suitable for even busy readers. Herwanta (2018) said that written works such as pentigraf were 
literary works that could be a means of reporting messages as well as faith. This opinion shows that pentigraf can be accepted by all groups.

\subsection{Pentigraf writing techniques}

Short story is one part of literature. Basically, literary works require a creative process in making them, including a pentigraf. The length of the story depends on the needs. Sumardjono \& Saini (1995) say that the short length of short stories depends on the limitations of the elements. Therefore, the short story is known as intrinsic and extrinsic elements.

In short stories known there are two main elements, namely intrinsic elements and extrinsic elements. Wellek \& Warren (1989) say that extrinsic elements are elements outside of literary works that cover history to the environment that forms literary works. Intrinsic elements are the constituent elements of the literature itself, such as characters, plots, settings, and others. One of the most important parts of this intrinsic element is the plot. It could be that the plot is said to be the main frame of the short story. The plot is a plot or storyline. According to Atmowiloto (2013), the plot originated from a story conflict.

The plot is also a determinant of story structure. In general, Kinoyosan (2009) divides three parts of the plot, namely opening, core, and ending. Opening must be written as attractive as possible to attract reading interest. The core is the main conflict in the story. Ending is the end of the story or resolution of the conflict. An interesting ending is an unpredictable ending.

Language in short stories should not be formal or scientific language, nor should language be too flowery so that it cannot be understood by the reader. Shirazy (2008) says that the language in writing good literature is a language that is able to invite dialogue with readers. This has been proven when carrying out the creative process in the form of the Ayat-Ayat Cinta novel. The experience and style of communicative language chosen by Habiburrahman El Shirazy can be used as a reference in writing short stories.

The Cilukba strategy is a strategy initiated by today's Indonesian writer, Ayu Utami. The basis of its formation is the theory of pleasure of curiosity (Utami, 2015). Enjoyment of wanting to know is found in the game Cilukba. The Cilukba strategy has the advantage of being able to make readers curious so they can attract reading interest.

Based on Ayu Utami's narrative in the Short Story Writing Workshop at the Malang City Library in 2014. The applied Cilukba strategy was able to improve the ability to write short stories of students in the Utan Kayu community. Some of the prifat writers' training classes which were held individually or in groups also received significant results when successfully implementing the Cilukba strategy. This proves that the Cilukba strategy has a positive influence in the creative process of writing short stories. Based on these considerations, the Cilukba strategy was chosen as a learning strategy to write a pentigraf for the millennial generation.

\section{METHODS}

This type of research is qualitative research. According to C. Edson in Sherman and Webb (1988) argue that qualitative research is a form of moral discourse to understand the past and present. The method used is the method of participatory observation. The participatory observation method is a qualitative research method that involves researchers to plunge while becoming the main actors in data collection and creation. The data used in this study is the national pentigraf published by the Pancasila Laboratory of the State University of Malang. Data collection techniques in this study there are three, namely (1) observation, (2) interviews, and (3) literature study. In this study, researchers were also actively involved in informing the publication of kebangsan pentigraf. The researcher took part in the training process to make pentigraf. There are three stages in making kebangsan pentigraf, namely (1) training, (2) making process, and (3) book launching. The three stages were carried out by researchers and young people from the Pancasila Cadre who were fostered by the UM Pancasila Laboratory. 


\section{RESULTS AND DISCUSSION}

This research produced a national pentigraf book entitled "I Found the Beauty of Diversity." This book was published in 2019 by the publisher of UM Press in collaboration with the Pancasila Study Center of the State University of Malang. There are 34 pentigrafs written by 10 members of the Pancasila Cadre.

The ten pentigraf writers are (1) Dona Ashari, (2) Dyan Nurvita Martvianti, (3) Hizam Alif Aditya, (4) Moch Rexy Qolbi, (5) Muhammad Wildan Bahtiar, (6) Muchammad Zulkifli Zuchdi, (7) Siti Saidah, (8) Hafizah Widya Amalia, (9) Izzul Islam Azalina, and (10) Juliana Jasmine. The pentigraf titles written by these ten writers are (1) I found the beauty of diversity, (2) Used bicycle for you, (3) Hand phone for Sari, (4) Beautiful tolerance in school, (5) Wrinkled laughter, (6) Obstructed Pole, (7) There are Stories in National Songs, (8) Doubts, (9) Journey, (10) Pipit Twist, (11) Selemah Ranting, (12) Coming soon my blossom bloom, (13) A peacock, (14) Only one friend who knew, (15) A word with a wrong meaning, (16) Humanizing humans, (17) Human crackle goodness, (18) Much acting without much talking, (19) Zainal, (20) Cici, (21) Rescue grass, (22) Mountain and school circles, (23) Unexpected goodness, (24) The beauty of this country, (25) Adit's curious sense, (26) Tirex friendship, (27) Endless struggle, (28) Black superman, (29) Enigma, (30) Great hand, (31) Only so, (32) Right foot, (33) Rawon and satay, (34) Sunday morning blessing.

These pentigraf writers come from diverse disciplinary backgrounds so the literacy scheme also varies. This is caused by members of the Pancasila Cadre as the main author, originating from various majors so that the resulting work also varies.

The stories made in the national pentigraf are themed about national values. This value is deliberately chosen because it is in accordance with the purpose of making a pentigraf which is to instill national values in the millennial generation. The stories told are also fictional, but the authors also do research in their making. The research data is obtained when writers interact in society. The interaction process is what is used in making stories. The stories that were raised were also stories that had been experienced by writers in the community but had not been published. Social facts especially tolerance are the main themes raised in this pentigraf.

\subsection{Stage of producing work}

First, the pre-training stage. Before making the book, the Pancasila Cadres were given training first in the Pancasila Laboratory. It aims to provide an initial scheme of pentigraf as well as the presentation of techniques for writing short stories of three paragraphs to participants. Before conducting the training, the authors formed a small team to succeed the activity. The small team consists of (1) Ardi Wina Saputra, (2) Abd. Mu'id Aris Shofa, and (3) Chair of the Pancasila Laboratory of the State University of Malang. The first and second names were the researchers themselves, the next was the manager of the Pancasila Cadre and the manager of the Pancasila Laboratory. The initial activities we did were (1) discussing the time and place of the training, (2) formulating the material given to the trainees, and (3) making examples of the national pentigraf as the participants' stimulus.

Second, the training phase. This stage is packaged in the form of discussion and writing at one of the cafes at the Pancasila laboratory. Packaging is made interesting so that the creative ideas of the trainees can emerge on their own. There were two sessions of training material, namely the delivery of techniques to write pentigraf and the delivery of national content as a form of pentigraf writing. After the material was delivered, participants were given two papers. The first paper contains an example of a pentigraf and the second paper is blank paper which is used as a tool in writing. Initially, many participants felt difficult and hesitant to try, but the team that had been formed tried to continue to strengthen the participants to be confident in writing. Twenty minutes later, several participants were able to produce one pentigraf. Participants who were able to produce a pentigraf were asked to read the notes to other participants. This turned out to be able to attract the interest of other participants to immediately complete at least one pentigraf in 
the training. Nearly all participants progressed alternately to read their pentigraf. At the end of the training, participants were given two weeks to complete three pentigraf. The completed pentigraf were collected by email.

Third, the stages of curating, editing, and giving illustrations. Pentigraf that have been collected via email are then downloaded by the curator. After that the curator distributes it to the editor and illustrator. The editor does the editing process by communicating to the curator and writer. On the other hand, illustrators have begun working on illustrations in several short stories which are considered necessary to be reinforced with images.

Fourth, the stage of layout and printing. After all the pentigraf were edited and some pentigraf were illustrated, the next step was the arrangement and printing. This stage is carried out by the publisher. In addition to arranging and printing, the publisher also manages ISBNs and publishes according to the amount desired by the customer.

After the book is published, the steps taken are socialization to the community. The socialization is done by book review. Participants who attended the book review activities came from various circles. The resulting pentigraf is perfect for all ages to read and can be taught to all walks of life. Pentigraf were also distributed to the school library and used as academic souvenirs as well as alternative readings to instill national values for their readers.

\section{CONCLUSIONS}

The incorporation of civic and literary education in order to educate the public to increasingly understand the value of nationality, was carried out by the Pancasila Cadre with a team from the Pancasila Laboratory of the State University of Malang. His form is the making of a national pentigraf. There are three main stages in making it, namely (1) training, (2) making, (3) publishing. The three stages were carried out by members of the Pancasila Cadre and were curated by the Pancasila Laboratory Team of the State University of Malang. The result of the process is a national pentigraf entitled "I Discover the Beauty of Diversity." There are 34 pentigraf in this book written by 10 members of the Pancasila Cadre. The technique used in this pentigraf is the Cilukba technique. The process of dissemination of their pentigraf is through print and writing mass media, social networking, and book surgery. It is hoped that pentigraf will be able to become a stimulus as well as a trigger for people to want to practice the values of nationality, and to innovate in learning Civic Education.

\section{REFERENCES}

Atmowiloto, A. 2013. Mengarang itu gampang. Jakarta: Gramedia Pustaka Utama.

Tjahjono, T. 2017. Pedagang jambu biji dari phnom penh dan cerita-cerita lainnya. Jakarta: Kosa Kata Kita. Herwanta, A. et al. 2018. Surga untuk pohon ulin dan cerita-cerita lainnya. Sidoarjo: Penerbit Buku Delima. Indradi, A. 2018. Kitab pentigraf penjaja kopi tengah hari. Mojokerto: Temalitera.

Indradi, A. 2018. Pentigraf sebagai penyambung benang putus dalam pembelajaran sastra. Proceeding Senabasa. Malang: Politeknik Negeri Malang.

Kinyosan, A. 2009. Jadi penulis fiksi? Gampang kok! Malang: Andi Publisher.

Mawarti, R.A. et al. 2018. Us, the society, and our Pancasila: A nowadays service-learning program to prepare the good citizen. Proceedings of the Annual Civic Education Conference: 131-134.

Priyanti, B.E. October 4, 2017. Yuk menulis pentigraf! Koran Surya.

Sherman, R.R. \& Webb, R.B. 2005. Qualitative research in education: Focus and methods. London and New York: UK Routledge Falmer.

Singh, A. 2014. Challenges and Issues of generation z. IOSR Journal of Business and Management 16(1): 59-63.

Taspcott, D. 2008. Grown up digital: How the net generation is changing your world. McGraw-Hill.

Shirazy, H.E. 2008. Tentang menulis karya sastra: Yang dicintai pembaca, yang menggugah minat baca. In Anwar Efendi (Ed.), Bahasa dan sastra dalam berbagai perspektif. Yogyakarta: Tiara Wacana.

Sumardjono, J. \& Saini K.M. 1995. Apresiasi kesusastraan. Jakarta: Gramedia

Utami, A. 2015. Menulis dan berpikir kreatif. Jakarta: Kepustakaan Populer Gramedia.

Wellek, R. \& Austin, W. 1989. Teori kesusastraan. Jakarta: Gramedia. 